\title{
MRI Imaging of Osmotic Demyelination Syndrome
}

\author{
Lokesh Rana*1, Dinesh Sood ${ }^{1}$, Narvir Chauhan ${ }^{1}$, Pooja Gurnal ${ }^{2}$ and Manjuswamy² \\ ${ }^{1}$ Department of Radio-diagnosis, India \\ ${ }^{2}$ Department of Anaesthesia, India
}

Received: 輩: December 11, 2018; Published: 眥: December 19, 2018

*Corresponding author: Lokesh Rana, Assistant Professor, Department of Radio-diagnosis, India

\begin{abstract}
Osmotic demyelination syndrome encompasses central pontine demyelination as well extrapontine demyelination and is seen in alcoholics and malnourished individuals associated with rapid correction of hyponatremia [1,2]. We present a case of 52 year old male presenting with weakness and dysarthria with characteristic MRI appearance [2].

Keywords: Osmotic; Pontine
\end{abstract}

\section{Case Report}

We present a case of a 52 year old chronic alcoholic patient presented with history of weakness in limbs and dysarthria for 10 days. He was admitted in our institute with hypotension, so IV fluids were also rushed to him. MR Scan was done which shows central pontine T2W and FLAIR hyperintensities with sparing of peripheral fibres. No restriction seen on DWI, NO blooming seen on GRE and No post gadolinium enhancement seen. Diagnosis of Osmotic demyelination syndrome was made.

\section{Discussion}

Osmotic demyelination syndrome encompasses central pontine demyelination as well extrapontine demyelination and is seen in alcoholics and malnourished individuals associated with rapid correction of hyponatremia [1-4].

\section{Clinical Presentation}

Patient presents with spastic paralysis, pseudo bulbar palsy and disorientation $[5,6]$.

\section{Key Imaging Diagnostic Clues}

1) Symmetric central pontine $T 2 W$ hyper intensity with sparing of periphery with trident shaped appearance [6,7].

2) Extra pontine sites commonly are basal ganglia and cerebral white matter $[7,8]$.

\section{Differentials}

Pontine ischemia-Asymmetric involving central and peripheral pontine fibers $[7,8]$.

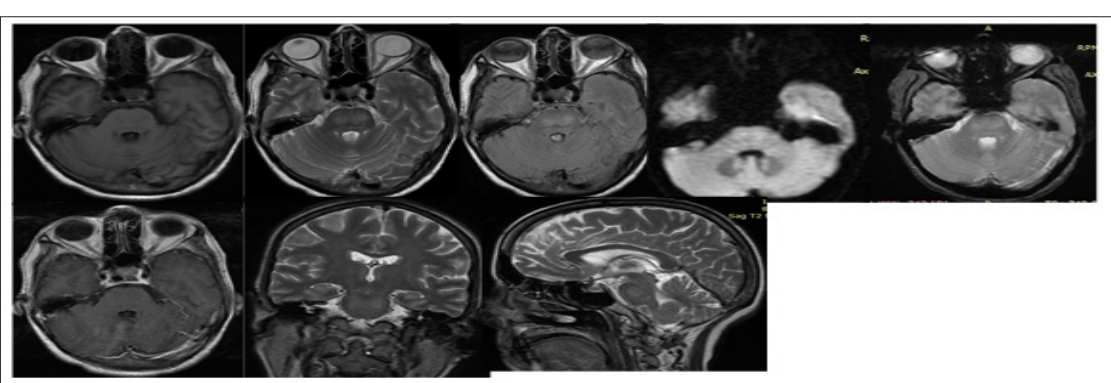

A 52 year chronic alchoholic patient presenting with weakness and dysarthria MRI images shows central pontine $T 2 W$ and $\operatorname{FLAIR}(b, c, g, h)$ hyperintensities with sparing of peripheral fibres. No restriction seen on DWI NO blooming seen on GRE and No post peripheral fibres. No restriction seen on DWN, gadolinium enhancement seen(d,e,f). Diagnosis of Osmotic demyelination syndrome was made.

Figure 1. 
Demyelinating disease-look for lesion elsewhere, horse-shoe type in particular $[1,8]$ (Figure 1).

\section{Conclusion}

Osmotic demyelination is common entity in alcoholics and malnourished individual. It is a treatable entity, so strong clinical suspicion and Typical diagnostic imaging feature on MR scan can lead to the diagnosis.

\section{References}

1. Howard SA, Barletta JA, Klufas RA, Saad A, De Girolami U (2009) Osmotic demyelination syndrome. Radiographics 29(3): 933-938.

2. Venkatanarasimha N, Mukonoweshuro W, Jones J (2008) AJR teaching file: symmetric demyelination. American Journal of Roentgenology 191(3): S34-S36.

ISSN: 2574-1241

DOI: $10.26717 / B J S T R .2018 .12 .002246$

Lokesh Rana. Biomed J Sci \& Tech Res

This work is licensed under Creative Commons Attribution 4.0 License

Submission Link: https://biomedres.us/submit-manuscript.php
3. Ruzek KA, Campeau NG, Miller GM (2004) Early diagnosis of central pontine myelinolysis with diffusion weighted imaging. AJNR Am J Neuroradiol 25(2):210-213.

4. Abbott R, Silber E, Felber J, Ekpo E (2005) Osmotic demyelination syndrome. BMJ 331(7520): 829- 830.

5. Lampl C, Yazdi K (2002) Central pontine myelinolysis. Eur Neurol 47(1): 3-10.

6. Kumar SR, Mone AP, Gray LC, Troost BT (2000) Central pontine myelinolysis: delayed changes on neuroimaging. J Neuroimaging 10(3): 169-172.

7. Laureno R, Karp BI (1997) Myelinolysis after correction of hyponatremia. Ann Intern Med 126(1): 57-62.

8. Miller GM, Baker HL, Okazaki H, Whisnant JP (1988) Central pontine myelinolysis and its imitators: MR findings. Radiology 168(3): 795-802.

$\begin{array}{ll}\text { BIOMEDICAL } & \text { Assets of Publishing with us } \\ \text { RESEARCHES } & \text { - Global archiving of articles } \\ \text { - Immediate, unrestricted online access }\end{array}$

